\title{
Effect of heat cycling on melting and crystallization of $\mathrm{PHB} / \mathrm{TiO}_{2}$ compounds
}

\author{
Nichollas Guimarães Jaques ${ }^{1}$, Ingridy Dayane dos Santos Silva', Manoel da Cruz Barbosa Neto', \\ Andreas Ries ${ }^{2}$, Eduardo Luis Canedo ${ }^{3}$ and Renate Maria Ramos Wellen ${ }^{1 *}$
}

\author{
${ }^{1}$ Departamento de Engenharia de Materiais, Universidade Federal da Paraíba - UFPB, \\ João Pessoa, PB, Brazil \\ ${ }^{2}$ Departamento de Engenharia Elétrica, Universidade Federal da Paraíba - UFPB, João Pessoa, PB, Brazil \\ ${ }^{3}$ Departamento de Engenharia de Materiais, Universidade Federal de Campina Grande - UFCG, \\ Campina Grande, PB, Brazil \\ *wellen.renate@gmail.com
}

\begin{abstract}
Compounds of poly(3-hydroxybutyrate) $(\mathrm{PHB})$ and titanium dioxide $\left(\mathrm{TiO}_{2}\right)$ with filler content between $1 \%$ and $10 \%$ were prepared in a laboratory internal mixer. The effect of heating and cooling rates on the crystallization and melting of $\mathrm{PHB} / \mathrm{TiO}_{2}$ compounds was investigated by differential scanning calorimetry (DSC). Melt and cold crystallization rates rise with increasing cooling/heating rates. A higher cooling rate translates to a lower melt crystallization temperature, while a higher heating rate results in a higher cold crystallization temperature. $\mathrm{TiO}_{2}$ promotes melt crystallization of PHB, behaving as a nucleant agent. The total crystallinity developed after melt and cold crystallization decreases for low levels of $\mathrm{TiO}_{2}$, i.e. $2 \%$ per weight, and is almost independent of the heating/cooling rate. The melting temperatures and rates are minimally affected by both the heating rate and filler content. The results suggest that the desired PHB microstructure can be controlled by filler content and adjusted heating/cooling rate.
\end{abstract}

Keywords: crystallization, DSC, melting, $P H B$, titanium dioxide.

\section{Introduction}

Polymers are fundamental for most common materials of our modern society because they present several desired features like lightness, easy processability, softness and low cost. As polymers are easily suitable for multiple uses, companies have been using them increasingly in various areas, such as packaging, automotive, medical-hospital, construction, electro-electronics industries among many others. Nevertheless, the production of the most useful polymers is based on fossil fuels. Considered to be non-biodegradable, they need decades to degrade and are an important source of pollution; in particular situations ecological disasters are verifiable. Concerned with the ecological equilibrium in nature, the society has made a lot of efforts to preserve the environment and to improve it where possible.

Engaged with this issue, polymer researchers are seeking answers on how to decrease the use of petroleum based products, thus reducing pollution and toxic volatiles emission. The use of natural and biodegradable polymers appears as good option. Among these polymers, the polyhydroxyalkanoates (PHAs) seem to be a good choice. PHAs are linear aliphatic polyesters produced in nature by bacterial fermentation of sugar or lipids. They are used by the microorganisms to store carbon and energy. Many different monomers can be combined within this family to give materials with different properties. In the present work poly(3-hydroxybutyrate) (PHB) was selected for studying ${ }^{[1-6]}$. PHB possesses good oxygen permeability and ultra-violet resistance, it is nontoxic and has been used in the packing industry for years; it is biocompatible and hence suitable for medical applications; due to its good mechanical properties and fast biodegradation rates, it has been employed in restaurant disposables, i.e., cups and cutleries. Furthermore, a wide range of additives and polymers may be incorporated to PHB, producing blends and compounds, to improve its performance and to expand its possible applications ${ }^{[7-12]}$.

Few articles are concerned with PHB crystallization and melting behaviour in the presence of fillers. For instance carbon black (CB) and babassu natural fibers induce PHB partial crystallization from the melt during cooling and partial cold crystallization on reheating ${ }^{[13-15]}$. The amount of polymer crystallization in each stage depends strongly on the cooling rate and the filler content, being the melting subtly affected by the fillers and experiment rates. In a recent study concerned with the influence of Zinc oxide $(\mathrm{ZnO})$ on the PHB crystallization ${ }^{[16]}$ it was found, that $\mathrm{ZnO}$ can neither be classified as a crystallization accelerator, nor as a crystallization inhibitor; the influence of zinc oxide on PHB crystallization is irregular and strongly dependent on its concentration, the melting of $\mathrm{PHB} / \mathrm{ZnO}$ compounds was little modified by $\mathrm{ZnO}$ content and heating/cooling rates tested.

To the best of our knowledge, there is not any study in the literature dealing with the melting as well as with the crystallization of $\mathrm{PHB} / \mathrm{TiO}_{2}$. From the literature is known that $\mathrm{TiO}_{2}$ could greatly improve the total solar reflectance, thus an appropriate content of $\mathrm{TiO}_{2}$ filler counteracts the thermal and photodegradation of plastics exposed to the sun. Antibacterial activity of $\mathrm{TiO}_{2}$ has been presented in the 
literature; the packing, textile and health-care industries have successfully used $\mathrm{TiO}_{2}$ in their products with the objective to reduce the risk of microorganism transmission. Adding to the biodegradable nature of $\mathrm{PHB}$ this research is dealing with a very promising compound ${ }^{[17-26]}$. The non-isothermal melt and cold crystallization, and melting processes of $\mathrm{PHB} / \mathrm{TiO}_{2}$ nanocompounds were investigated by differential scanning calorimetry (DSC) applying heating/cooling/reheating cycles (six different heating/cooling rates); thermal parameters related to these processes are presented with the main objective to provide a reference of crystallization and melting parameters for these compounds.

\section{Materials and Methods}

\subsection{Materials}

Poly(3-hydroxybutyrate) (PHB), a random copolymer with approximately $4 \%$ of 3 -hydroxyvalerate units, was supplied by PHB Industrial SA (Brazil). Its characteristic thermal transition temperatures are presented in Table 1. Melt crystallization $\left(\mathrm{T}_{\mathrm{mc}}\right)$, cold crystallization $\left(\mathrm{T}_{\mathrm{cc}}\right)$ and melting peak $\left(\mathrm{T}_{\mathrm{mp}}\right)$ temperatures were obtained during cooling and reheating, according to ASTM D-3418 standard, applying a cooling/heating rate of $10^{\circ} \mathrm{C} / \mathrm{min}$.

Titanium dioxide $\left(\mathrm{TiO}_{2}\right)$, was purchased from Evonik Degussa Co. (manufacturer's specification P25), with a surface area of $50 \mathrm{~m}^{2} / \mathrm{g}$ and a 75:25 anatase:rutile ratio. According to the manufacturer, the mean crystal sizes of the anatase and rutile phases are approximately 25 and $94 \mathrm{~nm}$, respectively.

\subsection{Methods}

$\mathrm{PHB}$ and $\mathrm{TiO}_{2}$ were used as received. The components were mixed for 10 minutes using a Haake Rheomix 600 laboratory internal mixer fitted with high intensity (roller type) rotors with the chamber wall kept at $190^{\circ} \mathrm{C}$ and a nominal rotor speed of $60 \mathrm{rpm}$. The $\mathrm{TiO}_{2}$ content ranged from $1 \%$ to $10 \%$ by weight.

Scanning electron microscopy images were acquired with a LEO 1430 unit, from Zeiss. The polymer samples were fractured in liquid nitrogen to avoid plastic deformation and coated with a carbon layer in order to avoid the accumulation of charges.

Thermal analysis was performed in a TA Instruments DSC Q20 V24.9 differential scanning calorimeter, under a nitrogen flow of $50 \mathrm{~mL} / \mathrm{min}$ to minimize oxidative degradation, to which the PHB is susceptible ${ }^{[27-29]}$. Samples of approximately $5 \mathrm{mg}$ were tested in aluminiun pans. A new specimen was used for each run. A blank curve was obtained for each heating/cooling/reheating stage to ensure that no contamination of the instrument had taken place. A thermal cycle of four stages was used: (1) heating from $25^{\circ} \mathrm{C}$ to $190^{\circ} \mathrm{C}$ (first heating stage); (2) isothermal stage: the samples were held at $190^{\circ} \mathrm{C}$ for 3 min to eliminate any residual crystallinity and erase the previous thermal history;

Table 1. Thermal transition temperatures $\left({ }^{\circ} \mathrm{C}\right)$ of $\mathrm{PHB}$ obtained by the authors.

\begin{tabular}{cccc}
\hline $\boldsymbol{T}_{\boldsymbol{g}}$ & $\boldsymbol{T}_{\boldsymbol{m} \boldsymbol{c}}$ & $\boldsymbol{T}_{c c}$ & $\boldsymbol{T}_{\boldsymbol{m} \boldsymbol{p}}$ \\
\hline 2 & 71.9 & 54.3 & 172.6 \\
\hline
\end{tabular}

(3) the melt was cooled to $20^{\circ} \mathrm{C}$ (cooling stage) and then (4) reheated to $190^{\circ} \mathrm{C}$ (second heating or reheating stage). Tests were conducted at constant heating and cooling rates of $5,7.5,10,15,20$ and $30^{\circ} \mathrm{C} / \mathrm{min}$.

Figure 1 shows a typical DSC output with the indicated cycles. Four thermal events were identified in most DSC tests. They were denominated as follows: $\mathrm{F}_{1}$ : melting during the first heating stage; $\mathrm{C}_{1}$ : melt crystallization during cooling; $\mathrm{C}_{2}$ : cold crystallization during reheating, and finally $\mathrm{F}_{2}$ : a second melting event.

For each thermal event, the starting and end points of departure from the underlying baseline were visually established in a plot of energy flow $(J)$ versus time $(t)$. The fractional crystallization (or melting) $x$ for the event was computed as a function of time by integration ${ }^{[30]}$ :

$$
x(t)=\frac{1}{E_{0}} \int_{t_{1}}^{t}\left|J\left(t^{\prime}\right)-J_{0}\left(t^{\prime}\right)\right| d t^{\prime}
$$

Where: $J_{0}$ is the virtual baseline during the event (a straight line in the present case), and $E_{0}$ is the total latent heat of the phase change:

$$
E_{0}=\int_{t_{1}}^{t_{2}}\left|J(t)-J_{0}(t)\right| d t
$$

and $t_{1}$ and $t_{2}$ are the initial and final times. The rate of the phase change (crystallization or melting) $c$ is:

$$
c(t)=\frac{d x}{d t}=\frac{\left|J(t)-J_{0}(t)\right|}{E_{0}}
$$

from which the peak (maximum) and average crystallization rates may be computed. The fractional crystallization/melting $x$ and the rate of crystallization/fusion $c$ may be expressed as functions of temperature $(T)$ by knowing the linear relationship between time and temperature during the event:

$$
T=T_{1}+\phi\left(t-t_{1}\right)
$$

Where: $T_{1}$ is the sample temperature at the starting point $t_{1}$, and $\phi$ is the (constant) rate of heating or cooling during the event. The specific latent heat of crystallization or melting

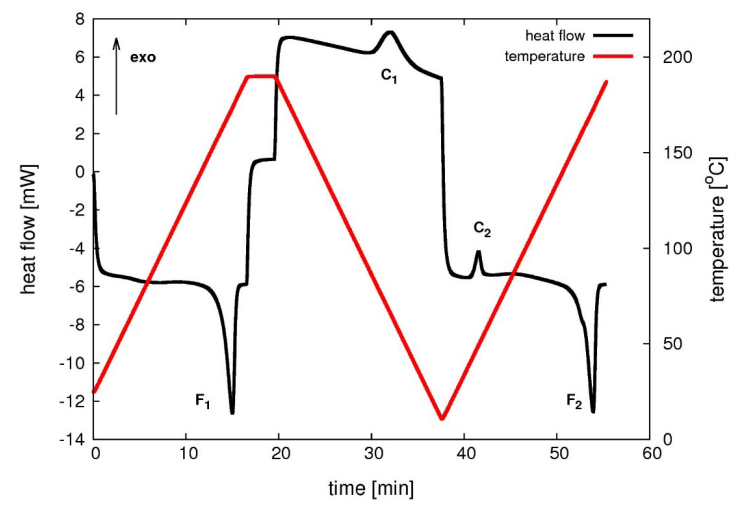

Figure 1. Typical DSC output for $\mathrm{PHB} / 1 \% \mathrm{TiO}_{2}$ heating/cooling/ reheating at $10^{\circ} \mathrm{C} / \mathrm{min}$ (exothermic peaks up), showing the phase change events: first melting $\left(\mathrm{F}_{1}\right)$, melt crystallization $\left(\mathrm{C}_{1}\right)$, cold crystallization $\left(\mathrm{C}_{2}\right)$, and second melting $\left(\mathrm{F}_{2}\right)$. 
(or enthalpy, because the phase change occurs at constant pressure) is computed from $E_{0}$, the polymer fraction $w_{P}$ and the sample mass $m_{S}$ :

$$
\Delta H=\frac{E_{0}}{w_{P} m_{S}}
$$

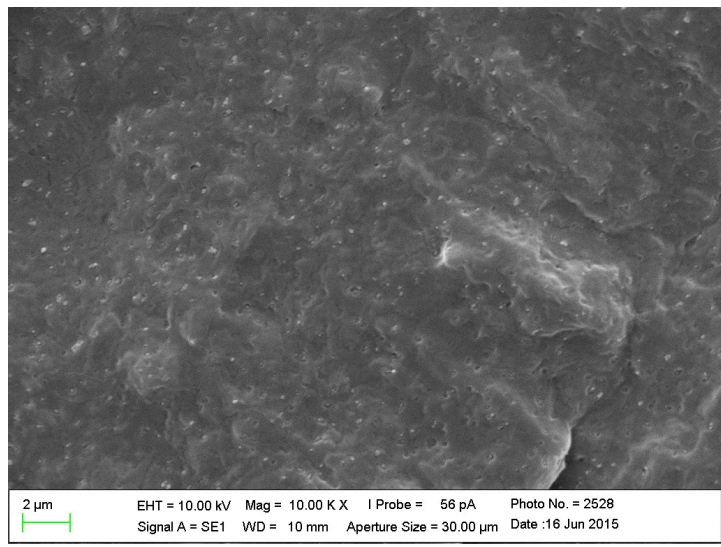

Figure 2. Scanning electron micrograph of $\mathrm{PHB} / 10 \% \mathrm{TiO}_{2}$, as obtained after mixing.
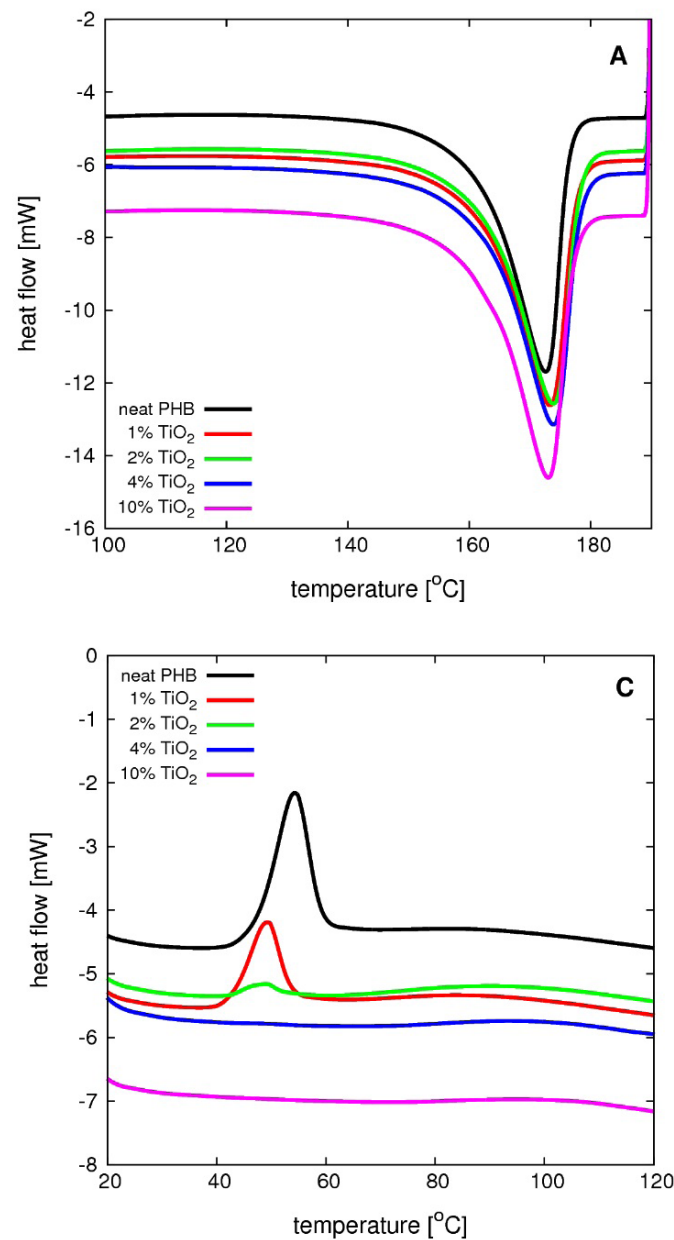

The mass crystallinity change $\Delta X_{C}$ during the event is estimated, taking into account the heat of fusion of PHB 100\% crystalline:

$$
\Delta X_{c}=\frac{\Delta H}{\Delta H_{m}^{0}}
$$

A value of $\Delta H^{0}{ }_{M}=146 \mathrm{~J} / \mathrm{g}$ at the equilibrium melting temperature $T^{0}{ }_{M}=185^{\circ} \mathrm{C}$ was previously reported in the literature $^{[31]}$

\section{Results and Discussions}

Figure 2 presents a SEM image of $\mathrm{PHB} / 10 \% \mathrm{TiO}_{2}$; despite the fact that $\mathrm{TiO}_{2}$ nanoparticles were not treated with a surface modifier, SEM image confirms their homogeneous distribution in the PHB matrix.

Figure 3 displays the DSC scans for neat PHB and all $\mathrm{PHB}-\mathrm{TiO}_{2}$ compounds for a fixed heating/cooling rate $\left(10^{\circ} \mathrm{C} / \mathrm{min}\right)$. Four events are recognized: the first melting (A), melt crystallization (B), cold crystallization (C) and the second melting (D).
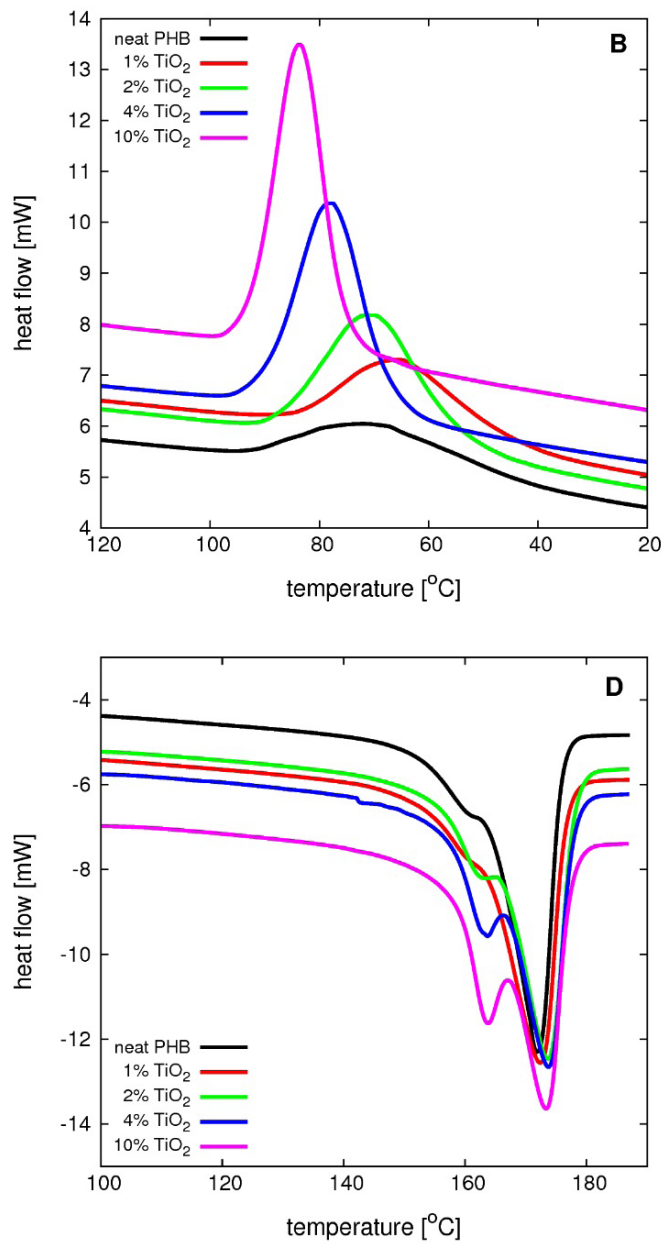

Figure 3. DSC scans of neat $\mathrm{PHB}$ and $\mathrm{PHB}-\mathrm{TiO}_{2}$ compounds obtained during the first heating (A), melt crystallization (B), cold crystallization (C) and second melting stages (D) (constant $10^{\circ} \mathrm{C} / \mathrm{min}$ scanning rate). 
As can be seen from Figure 3, the $\mathrm{TiO}_{2}$ filler has no significant influence on the first melting event (A). Melt crystallization and cold crystallization are the most affected events by the filler.

As $\mathrm{TiO}_{2}$ promotes melt crystallization in a similar way as a nucleant agent, the cold crystallization events vanish, as the crystallization process has been more completed during the melt crystallization event. The higher the filler content, the smaller is the observed cold crystallization peak.

Results gathered from previous works performed with neat PHB, PHB/Babassu, PHB/Carbon black and PHB/ZnO compounds about the influence of heating and cooling rates on PHB phase transition are very similar to these presented in this paper, in general, it is observed that PHB partially crystallizes from the melt during the cooling and partially cold crystallizes on reheating, and that the relative amount of polymer crystallizing in each stage strongly depends on the cooling rate and filler content. Regarding the influence of the fillers, addition of babassu filler in higher concentrations (10 to $50 \mathrm{wt} \%$ ) increased the crystallization peak temperature and crystallization rate; carbon black acted as a nucleating agent during PHB crystallization. The effect of $\mathrm{ZnO}$ on the PHB crystallization is unclear and strongly dependent on its concentration, behaving as an accelerator or an inhibitor upon changing of filler content ${ }^{[13-16]}$.

The second melting events (D) are different from the first melting events (A), a fact that can be seen from the shape of the peaks. Note that the first heating refers to the melting of PHB as obtained some time after processing (fully crystalline phase, no cold crystallization could be observed prior to first melting), whereas the second heating refers to the melting of PHB obtained during the more controlled cooling stage of the experiment. In this stage, the samples had undergone melt crystallization, followed by cold crystallization. During reheating stage, i.e., for the second fusion event (D) all samples showed complex (double) endothermic peaks upon addition of several filler contents: a first small melting peak followed by a larger peak at a higher temperature; this first small peak can also manifest as a shoulder of the larger peak. This behavior is more pronounced when the $\mathrm{TiO}_{2}$ content is high, and the heating rate is lowest (results not shown).

According to the literature ${ }^{[32-42]}$, such double peaks appearing in the fusion region may originate from (1) melting, recrystallization and re-melting during heating, (2) the presence of more than one crystal modification (polymorphism), (3) different morphologies (lamellar thickness, distribution, perfection or stability), (4) physical aging or/and relaxation of the rigid amorphous fraction, or (5) different molecular weight species. Although PHB degradation has been reported in some papers, for instance, $\mathrm{PHB} /$ Bentonite Organoclay compounds $^{[43]}$, in this work the degradation of PHB, as investigated by thermogravimetry (TG) (results not shown), was verified occurring at temperatures higher than $270^{\circ} \mathrm{C}$, that is, well above the melting range observed in Figure 3.

Figure 4 presents the development of the relative crystallinity as function of temperature for neat $\mathrm{PHB}$ and $\mathrm{PHB}-\mathrm{TiO}_{2}$ compounds; the data were obtained from DSC thermal scans. All plots have the sigmoidal shape characteristic of phase transformation in polymers.
One may observe the displacement of the sigmoid plots in Figure 4 to higher temperatures with increasing $\mathrm{TiO}_{2}$ concentration.

For a given cooling/heating rate and $\mathrm{TiO}_{2}$ content, the melt crystallization peak temperature is higher than the cold crystallization peak temperature, as shown in Figures 5 and 6. Numerical values are given in Table 2.

The melt crystallization peak temperature (Figure 5) decreases with an increase in the cooling rate and increases with an increase in the filler content.

The melt crystallization peak rates (Figure 7) are proportional to the cooling rate and strongly dependent on the $\mathrm{TiO}_{2}$ content. The cold crystallization temperature (Figure 6) and peak rate (Figure 8) increase with an increase in the heating rate when $\mathrm{TiO}_{2}$ filler concentration

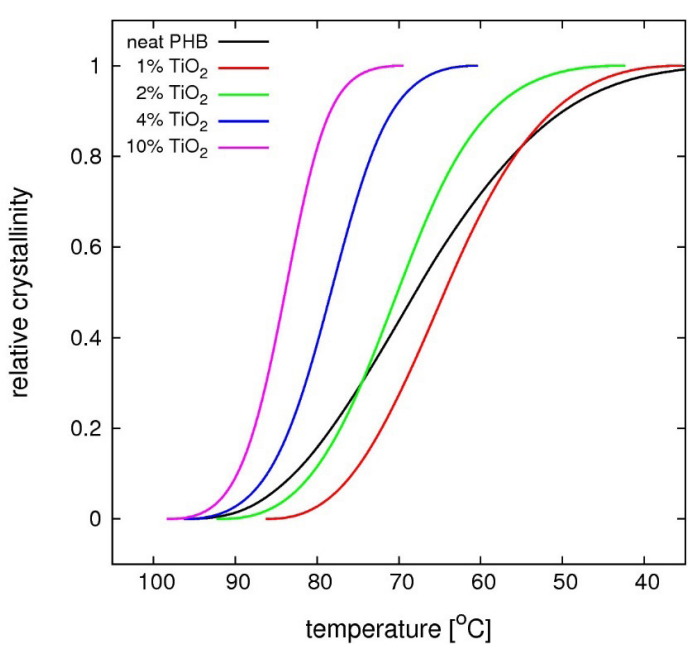

Figure 4. Relative crystallinity versus temperature for neat PHB and $\mathrm{PHB}-\mathrm{TiO}_{2}$ compounds considering melt crystallization at cooling rate $10^{\circ} \mathrm{C} / \mathrm{min}$.

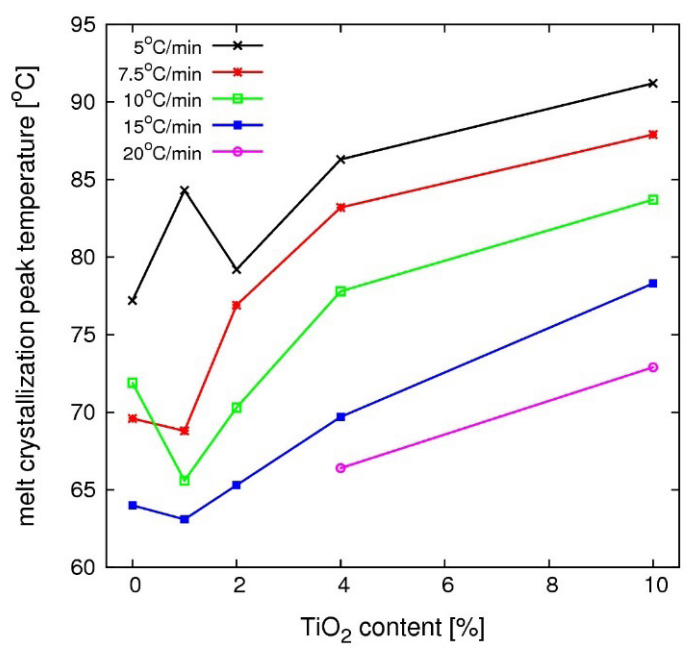

Figure 5. Crystallization peak temperature for melt crystallization of neat PHB and PHB-TiO ${ }_{2}$ compounds as a function of filler content and cooling rate. 
Table 2. Melt and cold crystallization parameters of compounds - Neat PHB.

\begin{tabular}{|c|c|c|c|c|c|c|c|c|}
\hline \multicolumn{9}{|c|}{ Neat PHB } \\
\hline \multicolumn{5}{|c|}{ Melt Crystallization } & \multicolumn{4}{|c|}{ Cold Crystallization } \\
\hline$\phi$ & $T_{m p}$ & $c_{\max }$ & $\Delta H_{m}$ & $\Delta X_{c}$ & $T_{m p}$ & $c_{\max }$ & $\Delta H_{m}$ & $\Delta X_{c}$ \\
\hline$\left({ }^{\circ} \mathrm{C} / \mathrm{min}\right)$ & $\left({ }^{\circ} \mathrm{C}\right)$ & $\left(\mathrm{min}^{-1}\right)$ & $(J / g)$ & $(\%)$ & $\left({ }^{\circ} \mathrm{C}\right)$ & $\left(\min ^{-1}\right)$ & $(J / g)$ & $(\%)$ \\
\hline 5 & 77.2 & 0.26 & 44.01 & 30.1 & -- & -- & -- & -- \\
\hline 7.5 & 69.6 & 0.25 & 27.81 & 19.1 & 50.8 & 1.06 & 11.45 & 7.8 \\
\hline 10 & 71.9 & 0.31 & 17.74 & 12.2 & 54.3 & 1.28 & 21.61 & 14.8 \\
\hline 15 & 64.0 & 0.54 & 5.21 & 3.6 & 64.0 & 1.52 & 38.66 & 26.5 \\
\hline 20 & -- & -- & -- & -- & 71.8 & 1.68 & 53.56 & 36.7 \\
\hline 30 & -- & -- & -- & -- & 81.2 & 1.98 & 28.20 & 19.3 \\
\hline \multicolumn{9}{|c|}{$\mathrm{PHB}+1 \% \mathrm{TiO}_{2}$} \\
\hline \multicolumn{5}{|c|}{ Melt Crystallization } & \multicolumn{4}{|c|}{ Cold Crystallization } \\
\hline$\phi$ & $T_{m p}$ & $c_{\max }$ & $\Delta H_{m}$ & $\Delta X_{c}$ & $T_{m p}$ & $c_{\max }$ & $\Delta H_{m}$ & $\Delta X_{c}$ \\
\hline$\left({ }^{\circ} \mathrm{C} / \mathrm{min}\right)$ & $\left({ }^{\circ} \mathrm{C}\right)$ & $\left(\min ^{-1}\right)$ & $(J / g)$ & $(\%)$ & $\left({ }^{\circ} \mathrm{C}\right)$ & $\left(\min ^{-1}\right)$ & $(J / g)$ & $(\%)$ \\
\hline 5 & 84.3 & 0.27 & 31.30 & 21.4 & -- & -- & -- & -- \\
\hline 7.5 & 68.8 & 0.30 & 26.78 & 18.3 & 46.9 & 1.13 & 4.21 & 2.9 \\
\hline 10 & 65.6 & 0.42 & 18.81 & 12.9 & 49.1 & 1.49 & 9.17 & 6.3 \\
\hline 15 & 63.1 & 0.57 & 7.72 & 5.3 & 56.3 & 1.82 & 34.0 & 23.3 \\
\hline 20 & -- & -- & -- & -- & 56.3 & 1.94 & 31.04 & 21.3 \\
\hline 30 & -- & -- & -- & -- & 78.0 & 2.12 & 51.95 & 35.6 \\
\hline \multicolumn{9}{|c|}{$\mathrm{PHB}+2 \% \mathrm{TiO}_{2}$} \\
\hline \multicolumn{5}{|c|}{ Melt Crystallization } & \multicolumn{4}{|c|}{ Cold Crystallization } \\
\hline$\phi$ & $T_{m p}$ & $c_{\max }$ & $\Delta H_{m}$ & $\Delta X_{c}$ & $T_{m p}$ & $c_{\max }$ & $\Delta H_{m}$ & $\Delta X_{c}$ \\
\hline$\left({ }^{\circ} \mathrm{C} / \mathrm{min}\right)$ & $\left({ }^{\circ} \mathrm{C}\right)$ & $\left(\min ^{-1}\right)$ & $(J / g)$ & $(\%)$ & $\left({ }^{\circ} \mathrm{C}\right)$ & $\left(\mathrm{min}^{-1}\right)$ & $(J / g)$ & $(\%)$ \\
\hline 5 & 79.2 & 0.36 & 35.99 & 24.7 & -- & -- & -- & -- \\
\hline 7.5 & 76.9 & 0.43 & 30.54 & 20.9 & -- & -- & -- & -- \\
\hline 10 & 70.3 & 0.47 & 28.49 & 19.5 & -- & -- & -- & -- \\
\hline 15 & 65.3 & 0.56 & 20.15 & 13.8 & 53.5 & 1.86 & 11.90 & 8.15 \\
\hline 20 & -- & -- & -- & -- & 59.6 & 2.24 & 27.08 & 18.5 \\
\hline 30 & -- & -- & -- & -- & 78.2 & 1.82 & 36.92 & 25.3 \\
\hline \multicolumn{9}{|c|}{$\mathrm{PHB}+4 \% \mathrm{TiO}_{2}$} \\
\hline \multicolumn{5}{|c|}{ Melt Crystallization } & \multicolumn{4}{|c|}{ Cold Crystallization } \\
\hline$\phi$ & $T_{m p}$ & $c_{\max }$ & $\Delta H_{m}$ & $\Delta X_{c}$ & $T_{m p}$ & $c_{\max }$ & $\Delta H_{m}$ & $\Delta X_{c}$ \\
\hline$\left({ }^{\circ} \mathrm{C} / \mathrm{min}\right)$ & $\left({ }^{\circ} \mathrm{C}\right)$ & $\left(\min ^{-1}\right)$ & $(J / g)$ & $(\%)$ & $\left({ }^{\circ} \mathrm{C}\right)$ & $\left(\mathrm{min}^{-1}\right)$ & $(J / g)$ & $(\%)$ \\
\hline 5 & 86.3 & 0.43 & 29.69 & 20.3 & -- & -- & -- & -- \\
\hline 7.5 & 83.2 & 0.56 & 31.12 & 21.3 & -- & -- & -- & -- \\
\hline 10 & 77.8 & 0.68 & 28.61 & 19.6 & -- & -- & -- & -- \\
\hline 15 & 69.7 & 0.71 & 24.12 & 16.5 & 52.9 & 2.69 & 0.67 & 0.5 \\
\hline 20 & 66.4 & 0.86 & 26.42 & 18.1 & 55.0 & 2.52 & 6.24 & 4.3 \\
\hline 30 & -- & -- & -- & -- & 72.5 & 1.95 & 15.16 & 10.4 \\
\hline \multicolumn{9}{|c|}{$\mathrm{PHB}+10 \% \mathrm{TiO}_{2}$} \\
\hline \multicolumn{5}{|c|}{ Melt Crystallization } & \multicolumn{4}{|c|}{ Cold Crystallization } \\
\hline$\phi$ & $T_{m p}$ & $c_{\max }$ & $\Delta H_{m}$ & $\Delta X_{c}$ & $T_{m p}$ & $c_{\max }$ & $\Delta H_{m}$ & $\Delta X_{c}$ \\
\hline$\left({ }^{\circ} \mathrm{C} / \mathrm{min}\right)$ & $\left({ }^{\circ} \mathrm{C}\right)$ & $\left(\min ^{-1}\right)$ & $(J / g)$ & $(\%)$ & $\left({ }^{\circ} \mathrm{C}\right)$ & $\left(\mathrm{min}^{-1}\right)$ & $(J / g)$ & $(\%)$ \\
\hline 5 & 91.2 & 0.58 & 36.52 & 25.0 & -- & -- & -- & -- \\
\hline 7.5 & 87.9 & 0.78 & 37.75 & 25.9 & -- & -- & -- & -- \\
\hline 10 & 83.7 & 0.92 & 35.56 & 24.4 & -- & -- & -- & -- \\
\hline 15 & 78.3 & 1.05 & 30.82 & 21.1 & -- & -- & -- & -- \\
\hline 20 & 72.9 & 1.21 & 31.54 & 21.6 & -- & -- & -- & -- \\
\hline 30 & -- & -- & -- & -- & -- & -- & -- & -- \\
\hline
\end{tabular}




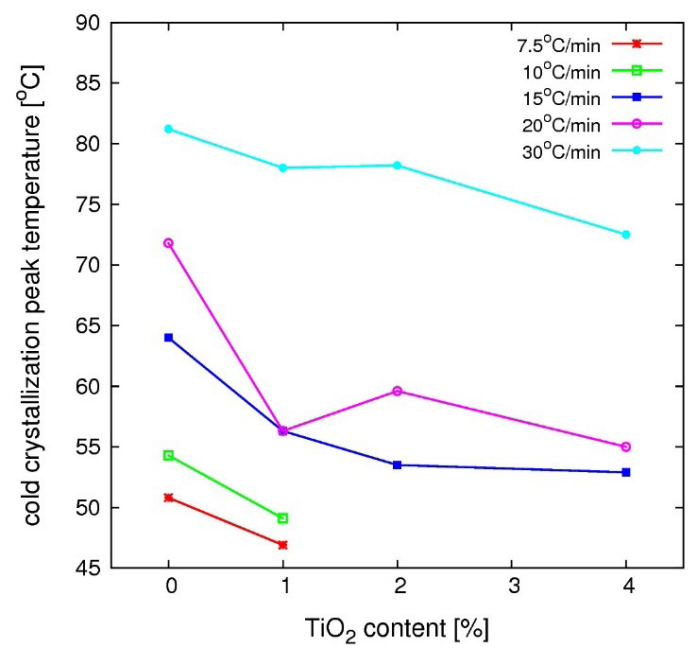

Figure 6. Crystallization peak temperature for cold crystallization of neat $\mathrm{PHB}$ and $\mathrm{PHB}-\mathrm{TiO}_{2}$ compounds as a function of filler content and heating rate.

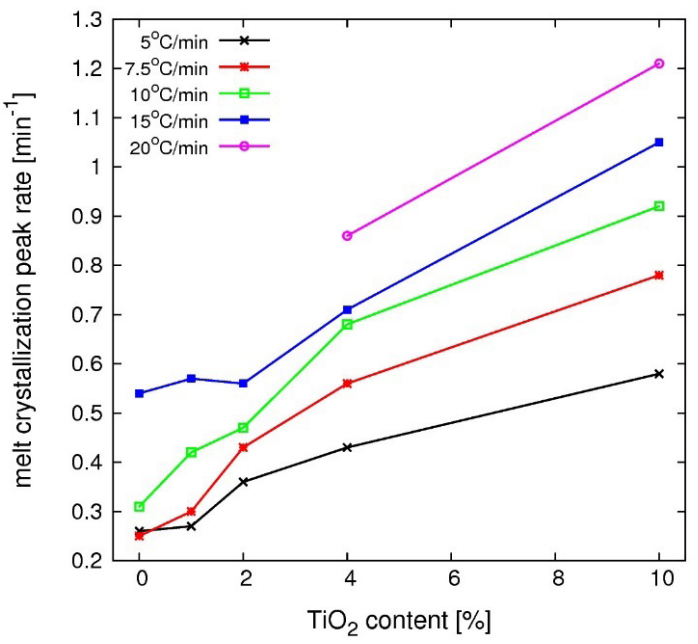

Figure 7. Crystallization maximum rate for melt crystallization of neat $\mathrm{PHB}$ and $\mathrm{PHB} / \mathrm{TiO}_{2}$ compounds as a function of the filler content.

is low (up to 1\%); their full dependence on filler content is unclear, but in general, the temperature decreases with an increase in the $\mathrm{TiO}_{2}$ content.

Figure 7 and 8 show the melt and cold crystallization peak rates which increase significantly with increasing filler concentration. This allows to classify titanium dioxide as a crystallization accelerator.

Figure 9 presents the results for the degree of crystallinity, which was computed using Equation 6. Initially, there is a decrease in the crystallinity for $\mathrm{PHB}$ compounds with $\mathrm{TiO}_{2}$ content up to $2 \%$. For higher filler concentrations no trend is observable; results are independent of the heating/cooling rate as well as of the filler content, even considering the high uncertainty of DSC estimates of crystallinity ${ }^{[44]}$. The observed

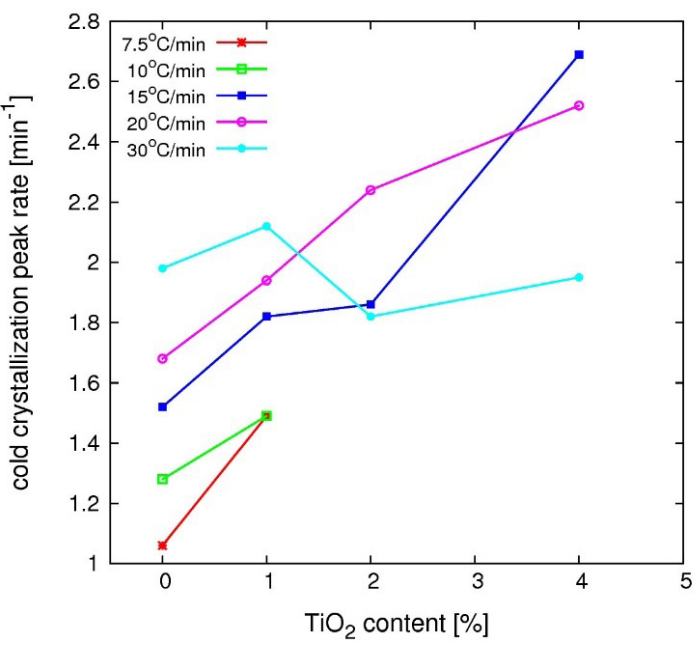

Figure 8. Crystallization maximum rate for cold crystallization of neat $\mathrm{PHB}$ and $\mathrm{PHB} / \mathrm{TiO}_{2}$ compounds as a function of the filler content.

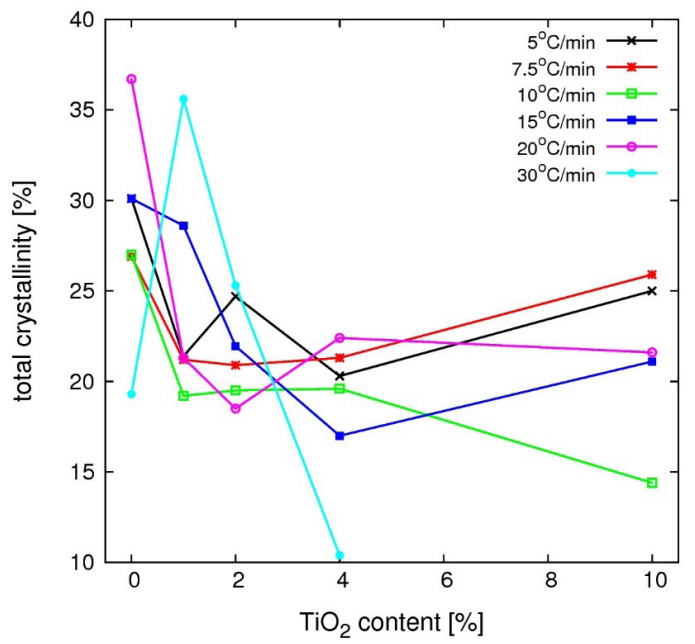

Figure 9. Total crystallinity developed during melt and cold crystallization as function of filler content for several cooling/ heating rates.

drop in crystallinity for the highest heating/cooling rate might be explained with a suppressed crystallization under the effect of fast cooling and heating process.

\section{Conclusions}

The cooling and heating rates have a strong influence on the melt and cold crystallization of PHB and its compounds with titanium dioxide. Increasing the cooling rate results in lower melt crystallization temperatures and promotes higher crystallization rates. Both, cold crystallization rates and cold crystallization peak temperatures increase with the heating rate. The addition of titanium dioxide accelerated the melt crystallization, suggesting $\mathrm{TiO}_{2}$ as a nucleant agent for PHB. The total crystallinity as obtained after melt and successive 
cold crystallization, decreases for low levels of $\mathrm{TiO}_{2}$, i.e., less than $2 \%$ per weight, and it is quite independent of the heating/cooling rate after that. The melting temperatures and rates are minimally affected by both the heating rate and filler content. Summing up, controlling the cooling and heating rates as well as adding $\mathrm{TiO}_{2}$ makes $\mathrm{PHB}$ crystallization changeable, and consequently its processing parameters, thus a cost-effective processing may be tailored.

\section{Acknowledgements}

Authors would like to thank PHB Industrial SA(Brazil) for kindly supplying PHB resin. NGJ, IDSS and MCBN thank CNPq for their scholarships.

\section{References}

1. Chen, G.-Q, \& Wu, Q. (2005). The application of polyhydroxyalkanoates as tissue engineering materials. Biomaterials, 26(33), 6565-6578. PMid:15946738. http:// dx.doi.org/10.1016/j.biomaterials.2005.04.036.

2. Zinn, M., Witholt, B., \& Egli, T. (2001). Occurrence, synthesis and medical application of bacterial polyhydroxyalkanoate. Advanced Drug Delivery Reviews, 53(1), 5-21. PMid:11733115. http://dx.doi.org/10.1016/S0169-409X(01)00218-6.

3. Barham, P. J., Keller, A., Otun, E. L., \& Holmes, P. A. (1984). Crystallization and morphology of a bacterial thermoplastic: poly-3-hydroxybutyrate. Journal of Materials Science, 19(9), 2781-2794. http://dx.doi.org/10.1007/BF01026954.

4. Porter, M. M., \& Yu, J. (2011). Crystallization kinetics of poly(3-hydroxybutyrate) granules in different environmental conditions. Journal of Biomaterials and Nanobiotechnology, 2(3), 301-310. http://dx.doi.org/10.4236/jbnb.2011.23037.

5. Doi, Y., Kanesawa, Y., Kunioka, M., \& Saito, T. (1990). Biodegradation of microbial copolyesters: poly(3-hydroxybutyrateco-3-hydroxyvalerate) and poly(3-hydroxybutyrate-co-4hydroxybutyrate). Macromolecules, 23(1), 26-31. http://dx.doi org $/ 10.1021 / \mathrm{ma} 00203 \mathrm{a} 006$

6. Bucci, D. Z., Tavares, L. B. B., \& Sell, I. (2007). Biodegradation and physical evaluation of PHB packaging. Polymer Testing, 26(7), 908-915. http://dx.doi.org/10.1016/j.polymertesting.2007.06.013.

7. Bordes, P., Pollet, E., \& Avérous, L. (2009). Nano-biocomposites: Biodegradable polyester/nanoclay systems. Progress in Polymer Science, 34(2), 125-155. http://dx.doi.org/10.1016/j. progpolymsci.2008.10.002.

8. Hufenus, R., Reifler, F. A., Fernández-Ronco, M. P., \& Heuberger, M. (2015). Molecular orientation in melt-spun poly(3-hydroxybutyrate) fibers: Effect of additives, drawing and stress-annealing. European Polymer Journal, 71, 12-26. http://dx.doi.org/10.1016/j.eurpolymj.2015.07.039.

9. Armentano, I., Fortunati, E., Burgos, N., Dominici, F., Luzi, F., Fiori, S., Jimenez, A., Yoon, K., Ahn, J., Kang, S., \& Kenny, J. M. (2015). Bio-based PLA-PHB plasticized blend films. Part I: Processing and structural characterization. LebensmittelWissenschaft + Technologie, 64(2), 980-988. http://dx.doi. org/10.1016/j.lwt.2015.06.032.

10. Kurusu, R. S., Siliki, C. A., David, E., Demarquette, N. R., Gauthier, C., \& Chenal, J. (2015). Incorporation of plasticizers in sugarcane-based poly(3-hydroxybutyrate) (PHB): Changes in microstructure and properties through ageing and annealing. Industrial Crops and Products, 72, 166-174. http://dx.doi. org/10.1016/j.indcrop.2014.12.040.

11. Ma, P., Xu, P., Chen, M., Dong, W., Cai, X., Schmit, P., Spoelstra, A. B., \& Lemstra, P. J. (2014). Structure-property relationships of reactively compatibilized $\mathrm{PHB} / \mathrm{EVA} / \mathrm{starch}$ blends. Carbohydrate Polymers, 108, 299-306. PMid:24751277. http://dx.doi.org/10.1016/j.carbpol.2014.02.058.

12. Mousavioun, P., Halley, P. J., \& Doherty, W. O. S. (2013). Thermophysical properties and rheology of PHB/lignin blends. Industrial Crops and Products, 50, 270-275. http://dx.doi. org/10.1016/j.indcrop.2013.07.026.

13. Wellen, R. M. R., Rabello, M. S., Araujo, I. C., Jr., Fechine, G. J. M., \& Canedo, E. L. (2015). Melting and crystallization of poly(3-hydroxybuturate). Effect of heating/cooling rates on phase transformation. Polímeros: Ciência e Tecnologia, 25(3), 296-304. http://dx.doi.org/10.1590/0104-1428.1961.

14. Wellen, R. M. R., Canedo, E. L., \& Rabello, M. S. (2015). Melting and crystallization of poly(3-hydroxybutyrate)/carbon black compounds. Effect of heating and cooling cycles on phase transition. Journal of Materials Research, 30, 3211-3226. http://dx.doi.org/10.1557/jmr.2015.287.

15. Vitorino, M. B. C., Cipriano, P. B., Wellen, R. M. R., Canedo, E. L., \& Carvalho, L. H. (2016). Nonisothermal melt crystallization of PHB/Babassu compounds. Kinetics ofcrystallization. Journal of Thermal Analysis and Calorimetry, 126(2), 755-769. http:// dx.doi.org/10.1007/s10973-016-5514-7.

16. Ries, A., Canedo, E. L., \& Wellen, R. M. R. (2016). Nonisothermal cold crystallization kinetics of poly(3-hydoxybutyrate) filled with zinc oxide. Thermochimica Acta, 637, 74-81. http:// dx.doi.org/10.1016/j.tca.2016.06.002.

17. Wang, S., \& Zhang, J. (2014). Effect of titanium dioxide ( $\left.\mathrm{TiO}_{2}\right)$ on largely improving solar reflectance and cooling property of high density polyethylene (HDPE) by influencing its crystallization behaviour. Journal of Alloys and Compounds, 617, 163-169. http://dx.doi.org/10.1016/j.jallcom.2014.07.191.

18. Supaphol, P., Thanomkiat, P., Junkasem, J., \& Dangtungee, R. (2007). Non-isothermal melt-crystallization and mechanical properties of titanium(IV) oxide nanoparticle-filled isotactic polypropylene. Polymer Testing, 26(1), 20-37. http://dx.doi. org/10.1016/j.polymertesting.2006.07.011.

19. Yang, T., Noguchi, T., Isshiki, M., \& Wu, J. (2014). Effect of titanium dioxide on chemical and molecular changes in PVC sidings during QUV accelerated weathering. Polymer Degradation \& Stability, 104, 33-39. http://dx.doi.org/10.1016/j. polymdegradstab.2014.03.023.

20. Olmos, D., Dominguez, C., Castrillo, P. D., \& Gonzalez-Benito, J. (2009). Crystallization and final morphology of HDPE: Effect of the high energy ball milling and the presence of TiO2 nanoparticles. Polymer, 50(7), 1732-1742. http://dx.doi. org/10.1016/j.polymer.2009.02.011.

21. Yew, S., Tang, H., \& Sudesh, K. (2006). Photocatalytic activity and biodegradation of polyhydroxybutyrate films containing titanium dioxide. Polymer Degradation \& Stability, 91(8), 18001807. http://dx.doi.org/10.1016/j.polymdegradstab.2005.11.011.

22. Scuderi, V., Buccheri, M. A., Impellizzeri, G., Di Mauro, A., Rappazzo, G., Bergum, K., Svensson, B. G., \& Privitera, V. (2016). Photocatalytic and antibacterial properties of titanium dioxide flat film. Materials Science in Semiconductor Processing, 42(Part 1), 32-35. http://dx.doi.org/10.1016/j.mssp.2015.09.005.

23. Lin, B., Luo, Y., Teng, Z., Zhang, B., Zhou, B., \& Wang, Q. (2015). Development of silver/titanium dioxide/chitosan adipate nanocomposite as an antibacterial coating for fruit storage. Lebensmittel-Wissenschaft + Technologie, 63(2), 1206-1213. http://dx.doi.org/10.1016/j.lwt.2015.04.049.

24. Kangwansupamonkon, W., Lauruengtana, V., Surassmo, S., \& Ruktanonchai, U. (2009). Antibacterial effect of apatite-coated titanium dioxide for textiles applications. Nanomedicine; Nanotechnology, Biology, and Medicine, 5(2), 240-249. PMid:19223243. http://dx.doi.org/10.1016/j.nano.2008.09.004.

25. Pleskova, S. N., Golubeva, I. S., \& Verevkin, Y. K. (2016). Bactericidal activity of titanium dioxide ultraviolet-induced 
films. Materials Science and Engineering C, 59, 807-817. PMid:26652436. http://dx.doi.org/10.1016/j.msec.2015.10.021.

26. Farias, E. A., Dionisio, N. A., Quelemes, P. V., Leal, S. H., Matos, J. M., Silva, E. C., Fo., Bechtold, I. H., Leite, J. R., \& Eiras, C. (2014). Development and characterization of multilayer films of polyaniline, titanium dioxide and CTAB for potential antimicrobial applications. Materials Science and Engineering C, 35, 449-454. PMid:24411400. http://dx.doi. org/10.1016/j.msec.2013.11.002.

27. Gogolewski, S., Jovanovic, M., Perren, S. M., Dillon, J. G., \& Hughes, M. K. (1993). The effect of melt-processing on the degradation of selected polyhydroxy acids: polylactides, polyhydroxybutyrate, and polyhydroxybutyrate-co- valerates. Polymer Degradation \& Stability, 40(3), 313-320. http://dx.doi. org/10.1016/0141-3910(93)90137-8.

28. El-Hadi, M., Schnabel, R., Straube, E., Müller, G., \& Riemschneider, M. (2002). Effect of melt processing on crystallization behavior and rheology of poly(3-hydroxybutyrate) (PHB) and its blends. Macromolecular Materials and Engineering, 287(5), 363-272. http://dx.doi.org/10.1002/1439-2054(20020501)287:5<363::AIDMAME363>3.0.CO;2-D.

29. Wagner, M. (2010). Thermal analysis in practice. Schwerzenbach: Mettler-Toledo.

30. Menczel, J. D., \& Prime, R. B. (2009). Thermal analysis of polymers. NewYork: Wiley.

31. Barham, P. J., Keller, A., Otun, E. L., \& Holmes, P. A. (1984). Crystallization and morphology of a bacterial thermoplastic: poly-3-hydroxybutyrate. Journal of Materials Science, 19(9), 2781-2794. http://dx.doi.org/10.1007/BF01026954.

32. Papageorgiou, G. Z., \& Panayiotou, C. (2011). Crystallization and melting of biodegradable poly(propylene suberate). Thermochimica Acta, 523(1-2), 187-199. http://dx.doi. org/10.1016/j.tca.2011.05.023.

33. Furushima, Y., Nakada, M., Takahashi, H., \& Ishikiriyama, K. (2014). Study of melting and crystallization behavior of polyacrylonitrile using ultrafast differential scanning calorimetry. Polymer, 55(13), 3075-3081. http://dx.doi.org/10.1016/j. polymer.2014.05.015.

34. Owen, A. J., Heinzel, J., Škrbić, Ž., \& Divjaković, V. (1992). Crystallization and melting behaviour of PHB and PHB/ HV copolymer. Polymer, 33(7), 1563-1567. http://dx.doi. org/10.1016/0032-3861(92)90139-N.

35. Gunaratne, L. M. W. K., \& Shanks, R. A. (2005). Multiple melting behaviour of poly(3-hydroxybutyrate-co-hydroxyvalerate) using step-scan DSC. European Polymer Journal, 41(12), 2980-2988. http://dx.doi.org/10.1016/j.eurpolymj.2005.06.015.
36. Schawe, J. E. K., \& Bergmann, E. (1997). Investigation of polymer melting by temperature modulated differential scanning calorimetry and its description using kinetic models. Thermochimica Acta, 304-305, 179-186. http://dx.doi.org/10.1016/ S0040-6031(97)00187-1.

37. Avila-Orta, C. A., Medellın-Rodriguez, F. J., Wang, Z.-G., Navarro-Rodriguez, D., Hsiao, B. S., \& Yeh, F. (2003). On the nature of multiple melting in poly(ethylene terephthalate) (PET) and its copolymers with cyclohexylene dimethylene terephthalate (PET/CT). Polymer, 44(5), 1527-1535. http:// dx.doi.org/10.1016/S0032-3861(02)00832-7.

38. Toda, A., Tomita, C., Hikosaka, M., \& Saruyama, Y. (1998). Melting of polymer crystals observed by temperature modulated d.s.c. and its kinetic modelling. Polymer, 39(21), 5093-5104. http://dx.doi.org/10.1016/S0032-3861(97)10075-1.

39. Asadinezhad, A., Khonakdar, H. A., Häußler, L., Wagenknecht, U., \& Heinrich, G. (2014). Crystallization and melting behavior of poly (ethylene succinate) in presence of graphene nanoplatelets. Thermochimica Acta, 586(20), 17-24. http:// dx.doi.org/10.1016/j.tca.2014.03.048.

40. Toda, A., Taguchi, K., Nozaki, K., \& Konishi, M. (2014). Melting behaviors of polyethylene crystals: an application of fast-scan DSC. Polymer, 55(14), 3186-3194. http://dx.doi. org/10.1016/j.polymer.2014.05.009.

41. Wang, N., Tu, R., Ma, X., Xie, Q., \& Jiang, X. (2013). Melting behavior of typical thermoplastic materials - An experimental and chemical kinetics study. Journal of Hazardous Materials, 262, 9-15. PMid:24007994. http://dx.doi.org/10.1016/j. jhazmat.2013.08.024.

42. Beekmans, L. G. M., van der Meer, D. W., \& Vancso, G. J. (2002). Crystal melting and its kinetics on poly(ethylene oxide) by in situ atomic force microscopy. Polymer, 43(6), 1887-1895. http://dx.doi.org/10.1016/S0032-3861(01)00748-0.

43. Almeida, T. G. (2015). Compósitos de Poli(butileno adioatoco-tereftalato e fibra de babaçu: efeito do processamento e do tipo e teor de carga. Universidade Federal de Campina Grande, Campina Grande.

44. Wellen, R. M. R., Rabello, M. S., Fechine, G. J. M., \& Canedo, E. L. (2013). The melting behaviour of poly(3-hydroxybutyrate) by DSC. Reproducibility study. Polymer Testing, 32(2), 215220. http://dx.doi.org/10.1016/j.polymertesting.2012.11.001.

Received: Oct. 10, 2016

Revised: July 20, 2017

Accepted: July 27, 2017 